\section{ECONOMICS}

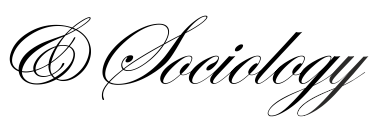

Dajcman, S. (2020). Demand for residential mortgage loans and house prices in the euro area. Economics and Sociology, 13(1), 40-51. doi:10.14254/2071789X.2020/13-1/3

\title{
DEMAND FOR RESIDENTIAL MORTGAGE LOANS AND HOUSE PRICES IN THE EURO AREA
}

\author{
Silvo Dajcman \\ University of Maribor, \\ Maribor, Slovenia \\ E-mail:silvo.dajcman@,um.si
}

Received: September, 2019

1st Revision: December, 2019

Accepted: February, 2020

DOI: $10.14254 / 2071-$

789X.2020/13-1/3

\begin{abstract}
This paper explores the determinants of demand for residential mortgage loans in the euro area, with a focus on the house prices-demand for loans nexus. We firstly identify the demand for residential mortgage loans and then empirically assess a model for an unbalanced panel of 13 euro area countries, covering the period 2003Q1-2016Q3. Our results show that the growth of house prices is positively associated with changes in demand for residential mortgage loans. A positive association was also found between GDP growth and changes in demand for mortgage loans. Growth in residential mortgage interest rates and changes in bank credit standards for residential mortgage loans are negatively associated with changes in demand for residential mortgage loans. We found that these associations generally became more significant after the start of the subprime mortgage crisis in the U.S. rather than before the crisis.
\end{abstract}

JEL Classification: E4, G21, G51

Keywords: mortgage loans, house prices, interest rates, subprime crisis

\section{Introduction}

Mortgage loans are the largest liability of euro area households towards euro area monetary financial institutions (MFI). According to European Central Bank (ECB) statistical data warehouse (ECB, 2017a), at the end of 2016, the outstanding residential mortgage debt ${ }^{1}$ of euro area residents towards the euro area's MFI amounted $€ 4.048$ trillion (approximately $38 \%$ of the euro area GDP), representing a $74.7 \%$ share of the total (residential mortgage plus consumer) loan liabilities of households towards the euro area's MFIs. The euro area data ${ }^{2}$ and international evidence (e.g., Mian \& Sufi, 2011; Jordà et al., 2014) show that house prices and residential mortgage market activity are positively related. As argued by (amongst others) Hempell and Sørensen (2010), Ciccarelli et al. (2015), and Basten and Koch (2016), credit market activity can be driven either by demand or the supply of credit. This is an empirical

\footnotetext{
${ }^{1}$ Note that ECB statistics for euro area applies the term "house purchase loans". In the relevant literature, however, the term "residential mortgage loans" is common and the paper, therefore, uses this term.

${ }^{2}$ According to ECB aggregate data on monetary financial institutions balance sheet (ECB, 2017a), the average annual growth rate of stock of residential mortgage loans in the euro area was 9.2\% between 1998 and 2007, and was $1.8 \%$ in the period 2008-2015. During the same periods, the average growth in house prices was $5.6 \%$ and $0.2 \%$ a year, respectively, according to the ECB statistical data warehouse (ECB, 2017b).
} 
research question of important economic policy relevance. If residential mortgage activity is demand-driven, economic policy aimed at controlling the house price cycle should resort to measures that affect households' borrowing capacity; if it is supply-driven, measures are needed that affect banks' capacity and willingness to lend (Crowe et al., 2011; Basten \& Koch, 2016).

Existing empirical research into the demand for residential mortgage loans (Jones, 1995; Dunsky, 1997; Ling \& McGill, 1998; Leece, 2006; Fitzpatrick \& McQuinn, 2007; Bokhari et al., 2013; Nobili \& Zollino, 2017) focuses on individual countries (mostly the U.S.), while the evidence for the euro area as a whole is still missing. This paper aims to fill this gap.

An important challenge in empirical investigation is identification of demand for residential mortgage loans. There are two major approaches to the challenge. One approach uses micro-level, individual household loan-application data (e.g., Jones, 1995; Follain \& Dunsky, 1997; Ling \& McGill, 1998; Leece, 2006; Bokhari et al., 2013; Basten \& Koch, 2016) to identify the demand for residential mortgages and to explain how different factors affect it. The other strand of literature applies macro-level (national) data to identify the demand for residential mortgages and to explain the house prices-demand for residential mortgage nexus (e.g., Holmes, 1993; Wolswijk, 2005; Fitzpatrick and McQuinn, 2007; Nobili and Zollino, 2017). The later strand of literature adopts a strict assumption to identify the demand for residential mortgages, i.e., a reduced-form equation, assuming that certain exogenous macroeconomic variables only explain variability in demand but not in the supply of mortgages and vice versa. This paper draws upon the more recent literature and adapts the approach of monetary policy transmission literature, whereby the demand and the supply of loans are identified using the results of bank lending surveys (see, e.g., Lown and Morgan, 2006; Hempell and Sørensen, 2010; Bassett et al., 2012; Ciccarelli et al., 2015; Dajcman, 2016, 2017). Euro Area Bank Lending Survey (EABLS) results, conducted by the European Central Bank, have been used. This approach is new to the literature on demand for residential mortgage loans.

Following the empirical literature (Holmes, 1993; Wolswijk, 2005; Fitzpatrick \& McQuinn, 2007; Nobili \& Zollino, 2016), house prices, income (GDP), and interest rates on residential mortgage loans and the deposits of households are identified as important macroeconomic determinants of residential mortgage demand in euro area. Resorting to the literature on credit market imperfections (e.g., Stiglitz and Weiss, 1981; Bernanke and Gertler, 1995; Lown and Morgan, 2006), our empirical model also evaluates whether bank credit standards explain the demand for residential mortgages, which is also novel to the literature on demand for residential mortgages.

The rest of the paper is organized as follows: section 1 reviews the literature; section 2 presents the empirical methodology, and section 3 presents and discusses the results. Finally, the last section concludes the paper.

\section{Literature review}

Theoretical models of demand for residential mortgages have two main strands. The first uses an analytical framework of life-cycle consumption models to analyse utilitymaximizing consumer decisions in certain economic conditions (i.e., prices, costs and returns are known) (e.g., Brueckner, 1994a; Jones, 1993, 1995; Follain \& Dunsky, 1997). Consumers maximize their life-cycle utility (life cycle in these models spans either two (e.g., Brueckner, 1994a; Follain \& Dunsky, 1997) or multiple time periods (Jones, 1993, 1995)) by optimizing housing consumption (housing services), non-housing consumption and their wealth. ${ }^{3}$ Debt

\footnotetext{
${ }^{3}$ Wealth is composed of initial wealth, savings created during the life cycle and house equity appreciation. (Savings are determined not just by income and consumption but also by the rate of return on the savings account (see, e.g., Brueckner, 1994a) or the rate of return on other risky assets (see, e.g., Follain and Dunsky, 1997). Jones (1993,
} 
creation increases consumers' available non-housing consumption but at the same time negatively impacts on wealth via lost investment opportunities (reduced savings) and interest payments on the debt. With restrictions on short-selling and non-negative mortgage debt, it is evident (see Brueckner, 1994a; Jones, 1993, 1995; Follain \& Dunsky, 1997; Leece, 2004) that demand for residential mortgage is determined by the relationship between interest rates on mortgages (mortgage loans) and the savings accounts (or a return on a risky asset). When interest rates on savings accounts (or return on a risky asset) exceed mortgage interest rates, a utility-maximizing consumer will demand the maximal amount of mortgage loan possible. A utility-maximizing consumer will not borrow at all when mortgage interest rates surpass interest rates on savings accounts (or the return on a risky asset) (Follain \& Dunsky, 1997). In Brueckner's (1994a) model, where the present value of future wealth also depends on the time preference/impatience of the consumer, utility-maximization solutions can be multiple-both corner solutions (maximum borrowing or no borrowing at all) or some intermediate level of borrowing are possible.

The second strand of theoretical models of demand for residential mortgages is modelled on the assumption of an uncertain economic environment, typically within a portfolio optimization framework (e.g., Alm \& Follain, 1984; Brueckner, 1994b; Flavin \& Yamashita, 2002). As noted by Leece (2004), several strong assumptions are needed in this case to derive analytical solutions to the demand for mortgage loans optimization problem, including a perfect capital market and continuous portfolio rebalancing. Bruckner (1994b) has shown that, in this case, corner solutions are less likely. When the rate of return on a risky asset (or the interest rate on the savings accounts) is uncertain, then even if it is higher than the interest rate on the mortgage loan, some consumers will not borrow (see Leece (2004) for a comprehensive analysis of these models).

Theoretical models of demand for residential mortgages can, to a certain extent, predict the effect that house price increases will have on demand for residential mortgages. Brueckner's model (1994a) predicts that when interest rates on savings accounts are higher than mortgage interest rates, house price increases lead utility-maximizing consumers to increase their demand for a mortgage (Leece, 2004).

In their theoretical model, Bokhari et al. (2013) dismiss the assumption of certain second-period house prices. They show that demand for mortgages depends on the distribution of house prices in the second period. If bankruptcy costs relative to the housing service are sufficiently low, house price appreciation will increase demand for mortgages amongst utilitymaximizing consumers.

Mian and Sufi (2011) analysed possible behavioural responses of utility-maximizing consumers following an increase in house prices. One type of consumer in the mortgage market is that of credit-unconstrained, long-lived homeowners. Referencing Sinai and Souleles (2005), and Campbell and Coco (2007), Mian and Sufi (2011) argue that these consumers will not increase demand for mortgages following house price appreciation. The second type of consumer includes credit-constrained homeowners. Mian and Sufi (2011) refer to OrtaloMagné and Rady (2006), and Lustig and Van Nieuwerburgh (2005), and argue that these consumers will positively adapt their demand for mortgages following a rise in house prices. The same response is expected from the third type of consumers - short-lived homeowners who plan to increase consumption during their life cycle by selling some of their house equity.

Empirical studies investigating the demand for residential mortgages mostly rely on micro-level household loan-application data to identify the demand for residential mortgages. Jones (1995) estimated a residential mortgage demand equation based on a sample of Canadian

1995) suggests that after-tax returns on non-housing savings must be considered. Follain and Dunsky (1997) also consider a version of a theoretical model in which taxes are non-neutral). 
household survey data. Follain and Dunsky (1997), and Ling and McGill (1998) used U.S. household survey data (the former study using Surveys of Consumer Finance data and the latter using data from the American Housing Survey of the U.S. Department of Commerce). Bokhari et al. (2013) obtained data from Fannie Mae's database on mortgages for single-family households, purchased by the institution. Leece (2006) drew upon data from the British Household Panel Survey and analysed demand for residential mortgages in the U.K. Basten and Koch (2016) used individual loan-application data from a specially designed Swiss online mortgage platform. Older empirical studies have been reviewed by Ling and McGill (1998) and Leece (2004).

Our research mostly refers to studies that use macro-level (national) data to identify and assess the determinants of demand for residential mortgages. Holmes (1993) investigated demand for residential mortgages in Northern Ireland and Scotland between 1960 and 1989; Wolswijk (2005) looked at the EU between 1982 and 2003; Fitzpatrick and McQuinn (2007) studied Ireland during the period 1996-2002; and Nobili and Zollino (2017) focused on Italy during the period 1986-2010. These studies faced an identification problem that studies using micro-level data do not. The problem arises because, at the aggregate (national) level, only data on outstanding residential mortgages are available. There are no aggregate data on the demand for and supply of residential mortgages. In order to identify the demand for mortgages, these studies resorted to the assumption that certain exogenous macroeconomic variables only explain demand and not the supply of mortgages and vice versa. Demand for mortgages could then be estimated using a reduced-form equation.

Existing empirical models also differ in terms of explanatory variables. Empirical models that use macro-level data to identify demand for residential mortgages and the determinants of demand for loans typically include the (disposable) income of households (or GDP) ${ }^{4}$ house prices, mortgage interest rates and some indicators of the financial wealth of households. ${ }^{5}$ Empirical models that use micro-level data to identify demand for residential mortgages use mortgage interest rates, interest rates on savings accounts (or the difference between the two interest rates), ${ }^{6}$ survey data on individual household incomes, ${ }^{7}$ the value (price) of property purchased and additional variables that specify other household characteristics, e.g., age, marital status and number of children etc. (see, e.g., Leece, 2004, for a review of these empirical studies).

On the basis of empirical studies, (disposable) income (or GDP) ${ }^{8}$ and house price increases can be expected to relate positively to demand for residential mortgages. Higher incomes make mortgages more "affordable" (Ling and McGill, 1997), while higher house prices demand a greater housing investment and thus create increased demand for mortgages. Studies by Holmes (1993), Wolswijk (2005), and Fitzpatrick and McQuinn (2007) support this notion as they found that higher income increases demand for residential mortgage loans. An opposing view is that presented by Nobili and Zollino (2016), who argue that a higher income makes house financing less dependent on bank loans, basing their claim on the Italian residential mortgage market. Holmes (1993), Wolswijk (2005), Fitzpatrick and McQuinn (2007), and Nobili and Zollino (2016) found a positive association between house prices and demand for residential mortgage loans. Higher mortgage rates increase financing costs;

\footnotetext{
${ }^{4}$ Holmes (1993) used GDP; Fitzpatrick and McQuinn (2007) used national income; while Wolswijk (2005), and Nobili and Zollino (2016) used disposable household income at national level.

${ }^{5}$ Holmes (1993), and Fitzpatrick and McQuinn (2007) did not use any variable for household wealth; Wolswijk (2005) used the stock price index. Following theoretical models, a rate of return for risky financial assets or savings account interest rates can be used.

${ }^{6}$ Some studies use after-tax interest rates (e.g., Jones, 1995; Follain and Dunsky, 1997).

${ }^{7}$ After-tax income may also be used (see Ling and McGill, 1998).

${ }^{8}$ Nobili and Zollino (2017) found that in Italy, higher disposable income reduces demand for residential mortgages.
} 
therefore, it is expected that they negatively impact on demand for residential mortgages, as found by Wolswijk (2005), Fitzpatrick and McQuinn (2007), and Nobili and Zollino (2016). It is less clear how greater financial wealth relates to demand for residential mortgages. Theoretically, greater non-housing wealth could lead households to build up their house equity or enable future homeowners to afford higher downpayments (Wolswijk, 2005). However, greater non-housing wealth makes house purchases more affordable with less recourse to mortgage debt creation (Ling and McGill, 1998). Both positive (e.g., Jones, 1995; Wolswijk, 2005) and negative (e.g., Ling and McGill, 1998) associations between non-housing wealth and demand for residential mortgages are evident in the empirical literature.

\section{Methodology}

The contribution of this research to existing literature on the demand for residential mortgages is identification of the demand for residential mortgages using responses from the EABLS. EABLS is performed on a quarterly basis and seeks a representative sample of euroarea banks from all euro area countries in order to assess supply and demand conditions (see, e.g., Berg et al. (2005) and ECB (2016) for a description of the survey). Banks (amongst others) are asked to assess how household demand for residential mortgage loans changed in the preceding quarter in comparison to the quarter before that. One strand of monetary policy transmission literature (Lown and Morgan, 2006; Hempell and Sørensen, 2010; Bassett et al., 2012; Ciccarelli et al., 2015; Dajcman, 2016, 2017) considers that the results of bank lending surveys are a good proxy for changes in demand for loans.

To design our empirical model, we followed Follain and Dunsky (1997), Jones (1995) and Wolswijk (2005), estimating a reduced-form equation of changes in demand for residential mortgages. Demand for residential mortgage loans was estimated by the following static panel data model (see, e.g., Baltagi, 2005; Greene, 2002):

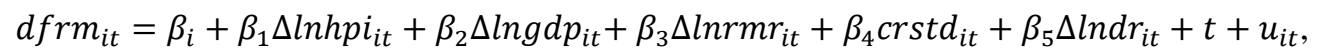

where $i=1, \ldots, N$ denotes a set of panel groups (euro-area countries), and $t=1, \ldots, T$ denotes time (in quarters). The dependent variable is the quarterly net percentage change in nominal demand for residential mortgage loans $\left(d f_{f r m} m_{i t}\right)$. Variables in the model are defined so that their stationarity is achieved. Because the dependent variable is measured in nominal terms and cannot be transformed into real terms (see Table 1 for a description of the variables), explanatory variables are also nominal. ${ }^{9}$ The set of explanatory variables (whose selection was guided by existing empirical studies of demand for residential mortgages) consists of quarteron-quarter logarithmic growth ${ }^{10}$ of the nominal house price index $\left(\Delta \operatorname{lnh} p i_{i t}\right)$, logarithmic quarter-on-quarter growth of the nominal GDP $\left(\Delta \operatorname{lng} d p_{i t}\right),{ }^{11} \operatorname{logarithmic}$ quarter-on-quarter growth in nominal interest rates on residential mortgage loans $\left(\Delta \operatorname{lnrm} r_{i t}\right)$, quarterly net percentage change in credit standards for residential mortgage loans $\left(\operatorname{crst}_{i t}\right)$ and the logarithmic quarter-on-quarter growth in nominal interest rates on deposits of households

\footnotetext{
${ }^{9}$ In the empirical literature, some authors use nominal data (e.g., Basten and Koch, 2016; Nobili and Zollino 2017), and some use real data (e.g., Wolswijk, 2005), while others use a mixture of both (e.g., Holmes, 1993).

${ }^{10}$ Quarter-on-quarter growth has been used rather than four-quarter growth because the dependent variable (net percentage change in demand for residential mortgage loans) is defined on a quarter-to-quarter basis.

${ }^{11}$ We decided to include GDP growth rather than growth of disposable income for two main reasons. Firstly, data on disposable income are not available at the quarterly frequency for some countries in the sample (Cyprus, Luxemburg and Malta). Secondly, because our study is based on aggregated national data, variability in disposable income closely follows variability in the GDP. Indeed, the coefficient of the correlation between GDP and disposable income for our sample is 0.996 .
} 
$\left(\Delta l n d r_{i t}\right)$ used as a proxy for changes in the non-housing (financial) wealth of households. ${ }^{12,13}$ $\beta_{i}$ denotes country (panel group)-specific fixed effects; $t$ denotes trend, and $u_{i t}$ is the remaining error term. The (country) fixed effects capture time-invariant unobservable cross-country heterogeneity (i.e., differences in the, e.g., institutional, cultural ${ }^{14}$ and demographic factors amongst euro area countries, conditioned that they are time-invariant for the observed time period) ${ }^{15}$ and tax systems etc. Model (1) was estimated with the fixed effects estimator (within estimator), applying Stata code xtscc.

The above specification only partially accounts for the heterogeneity of countries in the euro area. It assumes that demand for residential mortgage loans responds uniformly across euro area countries to increases in any explanatory variable. This is quite a restrictive assumption and may result in inconsistent parameter estimates if violated (Pesaran \& Smith, 1995). We, therefore, also considered the mean group (MG) estimator of Pesaran \& Smith (1995), which is known to produce consistent results:

$$
d f r m_{i t}=\beta_{i}+\beta_{1 i} \Delta l n h p i_{i t}+\beta_{2 i} \Delta l n g d p_{i t}+\beta_{3 i} \Delta l n r m r_{i t}+\beta_{4 i} \operatorname{crst} d_{i t}+\beta_{5 i} \Delta l n d r_{i t}+t_{i}+u_{i t} .
$$

The homogeneity of parameter estimates was checked by the Hausman test. Model (2) was estimated with the Stata code xtmg by Eberhartd (2011).

Model (1) was estimated for the entire period observed and for two sub-periods. The first sub-period preceded the start of the U.S. subprime mortgage crisis (2003Q1-2007Q2); the second was after the start of the crisis (2007Q3-2016Q3) - in order to assess whether the association between dependent and explanatory variables changed after the start of the subprime mortgage crisis in the U.S. Model (2) was estimated for the total period to evaluate whether (non-)heterogeneity of parameter estimates was an issue.

\section{Data and empirical results}

Models (1) and (2) were estimated using quarterly data for 13 euro area countries, including Austria, Belgium, Cyprus, France, Germany, Greece, Italy, Luxembourg, Malta, the Netherlands, Portugal, Slovenia and Spain (the euro area currently consists of 19 member countries, but some of these were not considered in this research, either because data on the net percentage change in demand for residential mortgage loans (our key variable) were not available (e.g., Estonia, Ireland and Finland) or were only available for a short period of time (Lithuania and Latvia). For Slovakia, data on other variables (notably quarterly GDP/disposable

\footnotetext{
${ }^{12}$ As already noted, from a theoretical perspective, either the rate of return on risky financial assets or a savings account interest rate can be used. In this research, we chose to use an average national deposit rate for two main reasons. Firstly, the deposit rate is preferable to the stock market index return because according to Eurostat data (Eurostat, 2017a), euro area households hold more wealth in deposits and currency (83.3\% on average for the observed sample of euro area countries) than in equity and investment fund shares (53.9\% of GDP). Secondly, we did not find publicly available data on the stock market index return for Malta and Cyprus. Data sample on the net financial wealth is also considerably shorter than for deposit rates.

${ }^{13}$ The list of explanatory variables in model (1) does not include a housing stock variable, the main reason being that a national breakdown of this variable is not available.

${ }^{14}$ Cultural differences between euro area countries can, for instance, be reflected in differences in typical household sizes. According to Eurostat (2017b), an average household in the euro area consisted of 2.5 people between 2009 and 2015, and was constant.

${ }^{15}$ Following a theoretical model (e.g., that of Bokhari et al. (2013)), the age of borrowers affects their decision on the amount of borrowing, with younger borrowers being more likely to borrow more. Differences in the population age structure between euro area countries (providing they were stable for the observed time period) were captured by the fixed effects.
} 
income) were unavailable. The resulting panel was unbalanced. Description of the variables and their time availability is presented in Table 1.

Table 1. Description of the variables

\begin{tabular}{|c|c|c|}
\hline Variable used & Description & Source \\
\hline $\begin{array}{l}\text { Quarterly net percentage change } \\
\text { in demand for residential } \\
\text { mortgage loans }\left(\text { ffrm }_{i t}\right)\end{array}$ & $\begin{array}{l}\text { Euro area banks' assessments showing changes in the "gross demand for } \\
\text { loans for house purchase[s]" during the previous quarter (i.e., total value } \\
\text { in nominal terms). Net percentage was calculated as the difference } \\
\text { between the sum percentage of the banks (participating in the EABLS) } \\
\text { that stated they observed a "considerable" or "somewhat" increased } \\
\text { demand for house purchase loans, and the sum percentage of banks that } \\
\text { reported a "considerable" or "somewhat" decreased demand for house } \\
\text { purchase loans (Berg et al., 2005; ECB, 2016). }\end{array}$ & $\begin{array}{c}\text { ECB Statistical Data } \\
\text { Warehouse } \\
\text { (https://sdw.ecb.europa.eu/) }\end{array}$ \\
\hline 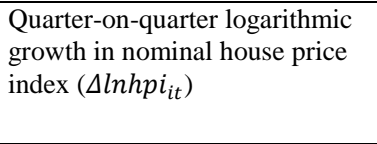 & $\begin{array}{l}\text { Quarterly nominal residential property price index (calculated as a three- } \\
\text { month average); see Bank for International Settlements (2017) for a } \\
\text { detailed description. Quarter-on-quarter growth was calculated as the first } \\
\text { difference in the logarithm of the house price index. }\end{array}$ & $\begin{array}{l}\text { Bank for International } \\
\text { Settlements Property Price } \\
\text { database } \\
\text { (http://www.bis.org/ } \\
\text { statistics/pp.htm }\end{array}$ \\
\hline $\begin{array}{l}\text { Quarter-on-quarter logarithmic } \\
\text { growth in nominal GDP } \\
\left(\Delta \operatorname{lng} d p_{i t}\right)\end{array}$ & $\begin{array}{l}\text { Quarterly nominal GDP (seasonally adjusted and working days adjusted). } \\
\text { Logarithmic quarter-on-quarter growth was calculated as the first } \\
\text { difference in the nominal GDP logarithm. }\end{array}$ & $\begin{array}{c}\text { Eurostat } \\
\text { (https://ec.europa.eu/ } \\
\text { eurostat/data/database) }\end{array}$ \\
\hline $\begin{array}{l}\text { Quarter-on-quarter logarithmic } \\
\text { growth in nominal interest rates } \\
\text { on new residential mortgage } \\
\text { loans }\left(\Delta l n r m r_{i t}\right)\end{array}$ & $\begin{array}{l}\text { Average nominal interest rate on new house purchase loans of all } \\
\text { maturities (lending for house purchases excluding revolving loans and } \\
\text { overdrafts, and convenience and extended credit card debt) to households } \\
\text { and non-profit institutions serving households. Quarterly loan-rate level } \\
\text { was calculated from monthly data as an unweighted three-month average. } \\
\text { Logarithmic quarter-on-quarter growth was calculated as the first } \\
\text { difference in the logarithm of nominal interest rate. }\end{array}$ & $\begin{array}{l}\text { ECB Statistical Data } \\
\text { Warehouse } \\
\text { (https://sdw.ecb.europa.eu/) }\end{array}$ \\
\hline $\begin{array}{l}\text { Quarterly net percentage change } \\
\text { in credit standards for } \\
\text { residential mortgage loans } \\
\left(\text { crstd }_{i t}\right)\end{array}$ & $\begin{array}{l}\text { Euro area banks' assessment showing changes in credit standards for } \\
\text { loans to households for house purchases during the previous quarter. Net } \\
\text { percentage was calculated as the difference between the sum percentage } \\
\text { of banks (participating in the EABLS) that stated they had } \\
\text { "considerably" or "somewhat" tightened credit standards for loans, and } \\
\text { the sum percentage of banks that reported "considerably" or "somewhat" } \\
\text { eased standards (see Berg et al. 2016). }\end{array}$ & $\begin{array}{c}\text { ECB Statistical Data } \\
\text { Warehouse } \\
\text { (https://sdw.ecb.europa.eu/) }\end{array}$ \\
\hline $\begin{array}{l}\text { Quarter-on-quarter logarithmic } \\
\text { growth in nominal interest rates } \\
\text { on new household deposits } \\
\left(\Delta \operatorname{lnd} r_{i t}\right)\end{array}$ & $\begin{array}{l}\text { Average nominal interest rate on new deposits of all maturities. Quarterly } \\
\text { level of a loan rate is calculated from monthly data as an unweighted } \\
\text { three-month average. Logarithmic quarter-on-quarter growth was } \\
\text { calculated as the first difference in the nominal interest rate logarithm. }\end{array}$ & $\begin{array}{l}\text { ECB Statistical Data } \\
\text { Warehouse } \\
\text { (https://sdw.ecb.europa.eu/) }\end{array}$ \\
\hline \multicolumn{3}{|c|}{$\begin{array}{l}\text { Data availability for specific countries: Austria, France, Germany, Italy and the Netherlands: 2003Q1-2016Q3; Belgium: 2005Q1-2016Q3; } \\
\text { Cyprus: 2009Q1-2016Q3; Greece: 2006Q1-2016Q3; Luxembourg: 2007Q1-2016Q3; Malta and Portugal: 2008Q1-2016Q3; Slovenia: } \\
\text { 2007Q1-2016Q3; Spain 2005Q4-2016Q3. }\end{array}$} \\
\hline
\end{tabular}

Before models (1) and (2) were estimated, panel unit root tests were used to ascertain that all the variables, as specified by the models, were stationary. No cointegration was established between the variables that were not stationary in the levels (test results are not presented here but are available from the author upon request).

The results of regression model (1) are presented in Table 2. The results of the Hausman test for the total observed period indicated that the hypothesis of non-systematic difference in parameter estimates between the fixed effects estimator (model (1)) and mean group estimator (model (2)) could not be rejected. We, therefore, concentrated on the results of the fixed effects estimator (model (1)).

The results indicated that in the euro area, house price growth, GDP growth, growth in residential mortgage interest rates and changes in credit standards are significantly contemporaneously related to changes in demand for residential mortgages. House price growth $\left(\Delta \operatorname{lnhpi}_{i t}\right)$ and changes in demand for residential loans in the euro area were found to be positively related yet significant only for the whole observed period and the period after the start of the U.S. subprime crisis. For the total observed period, a one-percentage-point increase in the (logarithmic) growth in house prices was found to be associated with a 3.72 net 
percentage points increase ${ }^{16}$ in demand for residential mortgage loans. In other words, the margin between EABLS banks stating that that they had observed a "considerable" or "somewhat" increased demand for residential mortgage loans, and the sum percentage of banks reporting a "considerable" or "somewhat" decreased demand for residential mortgage loans increased by 2.15 percentage points. This result is consistent with predictions from theoretical models and existing empirical surveys (e.g., Wolswijk, 2005; Fitzpatrick \& McQuinn, 2007; Nobili \& Zollino, 2016).

Table 2. The results of models (1) and (2)

\begin{tabular}{|c|c|c|c|c|}
\hline \multirow[t]{2}{*}{ Variables } & \multicolumn{2}{|c|}{ Total period } & \multirow{2}{*}{$\begin{array}{c}\begin{array}{c}\text { Pre sub-prime } \\
\text { mortgage crisis }\end{array} \\
\text { Model (1) } \\
\end{array}$} & \multirow{2}{*}{$\begin{array}{c}\begin{array}{c}\text { Post sub-prime } \\
\text { mortgage crisis }\end{array} \\
\text { Model (1) } \\
\end{array}$} \\
\hline & Model (1) & Model (2) & & \\
\hline$\Delta \operatorname{lnh} p i_{\text {it }}$ & $\begin{array}{r}371.982 * * * \\
(94.54331)\end{array}$ & $\begin{array}{r}644.977 * * \\
(264.075)\end{array}$ & $\begin{array}{r}350.8902 \\
(248.0384)\end{array}$ & $\begin{array}{r}274.5582 * * \\
(126.9245)\end{array}$ \\
\hline$\Delta \operatorname{lng} g p_{\mathrm{it}}$ & $\begin{array}{r}984.409 * * * \\
(206.6074)\end{array}$ & $\begin{array}{r}1221.78 * * * \\
(265.01)\end{array}$ & $\begin{array}{r}1477.499 * * * \\
(246.284) \\
\end{array}$ & $\begin{array}{r}862.3685^{* * * *} \\
(186.8049) \\
\end{array}$ \\
\hline$\Delta l n r m r_{\text {it }}$ & $\begin{array}{r}-149.049 * * * \\
(26.95962) \\
\end{array}$ & $\begin{array}{r}-170.79 * * * \\
(48.777) \\
\end{array}$ & $\begin{array}{r}-27.28288 \\
(80.23133) \\
\end{array}$ & $\begin{array}{r}-139.5797 * * * \\
(26.1876) \\
\end{array}$ \\
\hline $\operatorname{crstd}_{i t}$ & $\begin{array}{r}-.5291091 * * * \\
(.0754246)\end{array}$ & $\begin{array}{l}.295147 * \\
(.161722)\end{array}$ & $\begin{array}{r}-.3990537 * * \\
(.1700945) \\
\end{array}$ & $\begin{array}{r}-.4666269 * * * \\
(.0572376)\end{array}$ \\
\hline$\Delta l n d r_{\mathrm{it}}$ & $\begin{array}{r}2.63326 \\
(10.78426)\end{array}$ & $\begin{array}{r}-40.2373 \\
(30.8385)\end{array}$ & $\begin{array}{r}-65.11032 \\
(49.89932)\end{array}$ & $\begin{array}{r}8.708873 \\
(13.20789)\end{array}$ \\
\hline$t$ & $\begin{array}{r}.5507095 * * \\
(.253814) \\
\end{array}$ & $\begin{array}{r}1.00326 * * \\
(.408206) \\
\end{array}$ & $\begin{array}{r}-3.008105^{* *} \\
(1.118968) \\
\end{array}$ & $\begin{array}{r}1.279684 * * * \\
(.2525648)\end{array}$ \\
\hline $\begin{array}{l}R^{2} \text { (within) } \\
\text { RSME (root mean square error) } \\
\text { Hausman test statistic (p-value in the } \\
\text { brackets) }\end{array}$ & $\begin{array}{r}0.2985 \\
37.45 \\
17.06^{\mathrm{A}} \\
(0.001)\end{array}$ & $\begin{array}{r}/ \\
30.98 \\
8.73^{\mathrm{B}} \\
(0.1895)\end{array}$ & 0.2690 & 0.3632 \\
\hline
\end{tabular}

Source: Own calculations.

Notes: Fixed effects regression results of model (1) are presented. Driscoll-Kraay cross-sectional and temporal dependence robust standard errors are reported in the brackets under parameter estimates (Stata code xtscc of Hoechle (2007) was used for this purpose). The $10 \%, 5 \%$ and $1 \%$ significance levels of parameter estimates are denoted by $* * *$ and $* * *$, respectively. We

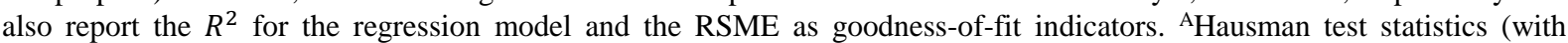
corresponding $p$-value in brackets) are reported as these were used to decide between random and fixed effects model. ${ }^{\mathrm{B}}$ Hausman test statistics and the significance level for the test of whether the difference in coefficients between the mean group (consistent estimator) and fixed effects (efficient but inconsistent under null) estimator is not systematic.

The regression coefficient for the GDP growth $\left(\Delta \operatorname{lng} d p_{i t}\right)$ showed that a one percentage point increase in GDP growth during the period studied was associated with a 9.84 net percentage points increase in demand for residential mortgage loans. Apparently, amongst all the variables included in model (1), a change in GDP growth had the largest impact on the change in demand for residential mortgage loans. The variable was also significant in both subperiods. The finding that GDP growth and changes in demand for residential mortgage loans are positively related is supported by existing empirical literature (e.g., Holmes, 1993). This result is also consistent with studies that use some other proxy for household income (see, e.g., Fitzpatrick and McQuinn (2007), who used national income, or Wolswijk (2005), who used disposable income). This finding is also consistent with studies that estimate the demand for residential mortgage loans based on individual loan-application data (e.g., Ling and McGill, 1998).

\footnotetext{
${ }^{16}$ It should be noted that variable $d f_{r m}$ it is expressed as a net percentage and was entered into the equation untransformed. Variables $\Delta l n h p i_{\text {it }}, \Delta l n g d p_{\text {it }}, \Delta l n r m r_{\text {it }}$ and $\Delta l n d r_{\text {it }}$ are expressed as differences in the natural logarithms, i.e., logarithmic growths (e.g., a $1 \%$ logarithmic growth is expressed as 0.01 ). A $1 \%$ (logarithmic) growth in variable $\Delta \operatorname{lnhpi} i_{\text {it }}$ is thus associated with a net percentage point increase in demand (for residential mortgage loans) equivalent to $0.01 * 371.982=3.72$.
} 
Growth in interest rates on residential mortgage loans $\left(\Delta l n r m r_{\text {it }}\right)$ and demand for residential mortgage loans are inversely related, which is consistent with theoretical and empirical literature (see, e.g., Wolswijk (2005), Fitzpatrick and McQuinn (2007), and Nobili and Zollino (2016)). A one percentage point increase in the growth of interest rates on residential mortgage loans was found to correspond with a 1.49 net percentage point reduction in demand for residential mortgage loans for the total observation period. The results indicated that interest rates on residential mortgage loans and demand for mortgage loans were not significantly related during the pre-subprime mortgage period.

Changes in bank credit standards $\left(\operatorname{crst} d_{i t}\right)$ and demand for residential mortgage loans were found to be inversely related: an increase in credit standards for residential mortgage loans amounting to one net percentage point was associated with a reduction in demand for residential mortgage loans amounting to 0.53 net percentage points for the total observed time period. The association between variables was found to be stronger in the second sub-period. The fact that the regression coefficient of the variable was statistically significant and negative is an indication that the residential mortgage market can be characterized as a non-frictionless market, which is consistent with the empirical evidence on credit market imperfections in the U.S. and euro area (see, e.g., Bassett et al., 2012; Ciccarelli et al., 2015; Dajcman, 2016, 2017)). Borrowers adapt to increased credit standards by demanding fewer (in terms of volume on the aggregate level) residential mortgage loans.

The regression coefficient of growth in interest on household deposits $\left(\Delta l n d r_{i t}\right)$ was found to be positive yet insignificant for the total period observed and the second sub-period. We thus find that changes in financial wealth growth, proxied by changes in interest rates on household deposits, do not explain variability in demand for residential mortgage loans in the euro area. As argued earlier, theoretically, a positive or negative relation can be predicted, and existing empirical surveys do not give a definitive answer as to the sign for the variable (see, e.g., Jones (1995) and Wolswijk (2005), who found a positive coefficient, and Ling and McGill (1998), who found a negative one).

The presented results indicate a strong negative interconnection between demand for residential mortgage loans and mortgage market conditions. This linkage may be detrimental to a macroeconomy, as recently shown by, e.g., Crowe et al., 2011; Mian and Sufi, 2011; and Jordà et al., 2014, since favourable mortgage market conditions may generate boom-bust cycles in the housing market. When house price bubbles burst, macroeconomic effects are generally worse if the boom phase of the cycle is supported by favourable credit (mortgage market) conditions (Crowe et al., 2011).

Mortgage market conditions are set by the level of mortgage rates and credit standards. Mortgage market conditions (and consequently the demand for houses) improve when mortgage rates and credit standards are reduced. Mortgage market conditions deteriorate when mortgage rates and credit standards increase. Given this interdependence between the mortgage market and housing market, economic policy can indirectly affect the housing market. To prevent the house prices bubble from forming, rapid expansion of household mortgage leverage may, therefore, call for economic policy measures that tighten credit market conditions, thus addressing demand or the supply of mortgage loans (Basten and Koch, 2016). It is empirically well established that monetary policy can affect credit market conditions by setting monetary policy rates (e.g., Lown and Morgan, 2006; Ciccarelli et al., 2015). Credit market conditions in general can be tightened either by reducing household borrowing capacity (e.g., increasing monetary policy rates; fiscal policy measures that affect the disposable income of households, including the introduction of new property taxes or increasing property taxes; and increasing loan-to-value limitations regulated by macroprudential authority) or by reducing lenders' ability and willingness to lend (measures that affect the balance sheets of banks, including 
capital and liquidity requirements, interest rates in capital markets and competition within the credit market) (see, e.g., Berg et. al., 2005; Crowe et al., 2011; Basten and Koch, 2016).

\section{Conclusion}

This paper used macro-level and bank lending survey data relating to 13 euro area countries to identify the determinants of demand for residential mortgage loans. Fixed effects and mean group panel data estimators were applied to estimate an empirical model. The results show that changes in demand for mortgage loans and growth in house prices and GDP, respectively, are positively related. Growth in interest rates on residential mortgage loans and changes in credit standards are inversely related to changes in demand for residential mortgage loans. Growth in interest rates on household deposits (or other alternative proxies for the financial wealth of households) is not a significant determinant of changes in demand for residential mortgage loans in the euro area. The results imply that favourable mortgage market conditions feed demand for mortgage loans and consequently may amplify the house price cycle. Economic policy can affect the housing price cycle by utilizing measures that tighten credit market conditions either by reducing households' borrowing capacity or by reducing lenders' ability and willingness to lend.

\section{References}

Alm, J., \& Follain J.R. (1984). Alternative mortgage instruments, the tilt problem, and consumer welfare. Journal of Financial and Quantitative Analysis, 19(1), 113-126.

Baltagi, B.H. (2005). Econometric Analysis of Panel Data models. Third Edition. Chichester: John Wiley \& Sons Ltd.

Bank for International Settlements. (2017). Selected representative residential property price series - data documentation" Available:http://www.bis.org/statistics/pp_selected_documentation.pdf.

Bassett, F.W., Chosak M.B., Driscoll J.C., \& Zakrajsek E. (2012). Changes in bank lending standards and the macroeconomy. Federal Reserve Board Finance and Economics Discussion Series paper No. 2012-24.

Basten, C., \& Koch C. (2016). The causal effect of house prices on mortgage demand and mortgage supply: evidence from Switzerland. BIS Working Papers No. 555.

Berg, J., van Rixtel A., Ferrando A., de Bondt G., \& Scopel S. (2005). The bank lending survey for the Euro area. European Central Bank Occasional Paper.

Bernanke, B.S., \& Gertler M. (1995). Inside the Black Box: The Credit Channel of Monetary Policy Transmission. Journal of Economic Perspectives, 9(4), 27-48.

Bokhari S., Torous W., \& Wheaton W. (2013). Why did Household Mortgage Leverage Rise from the mi-1980s until the Great Recession? Paper presented at the 2013 Annual Meeting of American Economic Association, Jan 05, 2013.

Brueckner, J.K. (1994a). The Demand for Mortgage Debt: Some Basic Results. Journal of Housing Economics, 3(4), 251-262.

Brueckner, J.K. (1994b). Consumption and investment motives and the portfolio choices of homeowners. Journal of Real Estate Finance and Economics, 15(2), 159-180.

Campbell, J., \& Cocco J. 2007. How do house prices affect consumption? Evidence from micro data.Journal of Monetary Economics, 54(3), 591-621.

Ciccarelli, M., Maddaloni A., \& Peydró J.L. (2015). Trusting the bankers. A new look at the credit channel of monetary policy" Review of Economic Dynamics 18(4): 979-1002. 
Crowe, C., Dell' Aricciac G., Igan D., and Rabanal P. (2011). Policies for Macrofinancial Stability. Options to Deal with Real Estate Booms. IMF Statt Discussion Note SDN11/02.

Dajcman, S. (2016). The Bank Lending Channel of Monetary Policy and its Macroeconomic Effects: Evidence from a Sample of Selected Euro Area Countries. Inzinerine EkonomikaEngineering Economics, 27(2), 124-133.

Dajcman, S. (2017). Bank risk aversion and the risk-taking channel of monetary policy in euro area. Panoeconomicus, 64(5), 607-621.

Eberhardt, M. (2011). XTMG: Stata module to estimate panel time series models with heterogeneous slopes. Statistical Software Components S457238, Boston College Department of Economics.

ECB. (2016). Bank lending survey for the euro area. Glossary. European Central Bank: Frankfurt.

ECB. (2017a). Lending for house purchase vis-a-vis euro area households reported by MFI excluding ESCB in the euro area (stock). Available: http://sdw.ecb.europa.eu/quickview.do?SERIES_KEY=117.BSI.M.U2.N.A.A22.A.1.U2 $.2250 . Z 01$.E\&start=\&end=\&submitOptions. $\mathrm{x}=0$ \& submitOptions. $\mathrm{y}=0 \&$ trans $=\mathrm{AF}$.

ECB. (2017b). Residential property prices. Available: http://sdw.ecb.europa.eu/quickview.do?SERIES_KEY=129.RPP.A.I8.N.TD.00.3.00\&st art $=\&$ end $=\&$ submitOptions $. x=0 \&$ submitOptions. $y=0 \&$ trans $=Y P C$.

Eurostat. (2017a). Financial balance sheets. Available: http://appsso.eurostat.ec.europa.eu/nui/show.do?dataset=nasq_10_f_bs\&lang=en.

Eurostat. (2017b). Average household size - EU SILC survey. Available: http://appsso.eurostat.ec.europa.eu/nui/show.do?dataset=ilc_lvph01\&lang=en.

Flavin, M. \& Yamashita T. (2002). Owner-Occupied Housing and the Composition of the Household Portfolio", American Economic Review, 92(1), 345-362.

Fitzpatrick, T., \& McQuinn K. (2007). House prices and mortgage credit: Empirical evidence for Ireland. The Manchester School, 75(1), 82-103.

Follain, J.R., \& Dunsky R.M. (1997). The Demand for Mortgage Debt and the Income Tax. Journal of Housing Research, 8(2), 155-199.

Greene, W.H. (2002). Econometric Analysis, Fifth Edition. New Jersey: Prentice Hall.

Hempell, H.S., \& Sørensen K. 2010. The impact of supply constraints on bank lending in the euro area - crisis induced crunching? European Central Bank Working Paper Series, No. 1262.

Hoechle, D. (2007). Robust standard errors for panel regressions with cross-sectional dependence. The Stata Journal, 7(3), 281-312.

Holmes, M. J. (1993). The Demand for Building Society Mortgage Finance in Northern Ireland and Scotland. Regional Studies, 27(2), 103-108.

Jones, L.D. (1993). The demand for home mortgage debt. Journal of Urban Economics, 33(1), $10-28$.

Jones, D. L. (1995). Net wealth, marginal tax rates and the demand for home mortgage debt. Regional Science and Urban Economics, 25(3), 297-322.

Jordà. Ò., Schularick M., \& Taylor A.M. (2014).The Great Mortgaging: Housing Finance, Crises, and Business Cycles. Federal Reserve Bank of San Francisco Working Paper Series No. 2014-23.

Leece, D. (2004). Economics of the Mortgage market: Perspective on Household Decision Making. Oxford: Blackwell Publishing.

Leece, D. (2006). Testing a Basic Theoretical Model of Mortgage Demand on United Kingdom Data. Applied Economics, 38(17), 2037-2051.

Ling, D.C., \& McGill G.A. (1998). Evidence on the Demand for Mortgage Debt by OwnerOccupants. Journal of Urban Economics, 44(3), 391-414. 
Lown, C.S., \& Morgan D. P..(2006). The credit cycle and the business cycle: new findings from the Loan officer opinion survey. Journal of Money, Credit, and Banking, 38(6), 15751597.

Lustig, H., \& Van Nieuwerburgh S. (2005). Housing collateral, consumption insurance and risk premia: an empirical perspective. Journal of Finance, 60(3), 1167-1219.

Mian, A.R., and Sufi A. (2011). House-prices, home equity-based borrowing, and the U.S. household leverage crisis. American Economic Review, 101(5), 2132-56.

Nobili, A., and Zollino G. (2017). A structural model for the housing and credit market in Italy" Journal of Housing Economics, 36(June), 73-87.

Ortalo-Magné, F., \& Rady S. (2006). Housing market dynamics: on the contribution of income shocks and credit constraints. Review of Economic Studies, 73(2), 459-485.

Pesaran, M.H. \& Smith R. (1995). Estimation of Long-run Relationships from Dynamic Heterogeneous Panels. Journal of Econometrics, 68(1), 79-11.

Sinai, T. \& Souleles N.S. (2005). Owner-occupied housing as a hedge against rent risk. Quarterly Journal of Economics, 120(2), 763-89.

Stiglitz, J.E., \& Weiss A. (1981). Credit Rationing in Markets with Imperfect Information. The American Economic Review, 71(3), 393-410.

Wolswijk, G. (2005). On some fiscal aspects on mortgage debt growth in the EU. European Central Bank Working Paper Series No. 526. 